DOI: $10.2478 / \mathrm{v} 10129-011-0022-1$

Audrone Mankeviciene ${ }^{1}$, Skaidre Suproniene ${ }^{1}$, Irena Brazauskiene ${ }^{1}$, Elvyra Gruzdeviene ${ }^{2}$

\author{
${ }^{1}$ Institute of Agriculture, Lithuanian Research Centre for Agriculture and Forestry, \\ Instituto aleja 1, Akademija, LT-58344 Kèdainiai distr.; ${ }^{2}$ Upyte Experimental \\ Station of the Lithuanian Research Centre for Agriculture and Forestry \\ Linininkų 3, Upytė LT- 38294, Panevėžys distr.
}

\title{
NATURAL OCCURRENCE OF FUSARIUM MYCOTOXINS IN OIL CROP SEED
}

\section{ABSTRACT}

Oilseeds are a perfect medium for microfungi spread and mycotoxin production. With increasing demand for oil crop produce such research has gained a special relevance since research evidence on this issue is scarce. During 2007-2009, prevalent fungi genera, including Fusarium genus, potential producer of deoxynivalenol (DON), zearalenone (ZEA), T-2 toxin (T-2) etc. were determined in our tests. The ELISA immunoenzymatic method and Veratox Fast kits were used to identify and quantify mycotoxins, while Fusarium fungi species were identified using conventional fungi determination techniques. Higher Fusarium fungi contamination level was found on linseed compared with that on spring or winter rapeseed. The difference was even more obvious in different experimental years, however, having identified Fusarium species, F. avenaceum and F. oxysporum were found to be prevalent in the seed of all crop species tested. In 2009, spring rape samples were found to contain $F$. dimerum which is a significant human pathogen.

The presence of DON was identified in $18.2-100 \%$, ZEA in $40-100 \%$, and T-2 toxin in $100 \%$ of seed samples of all oil crop species tested. From the food safety viewpoint, the concentrations determined did not exceed the levels hazardous for health, laid out in the EU regulations, however, the effect of low toxin concentrations is slow and the negative consequences manifest themselves only after some time and in various forms, which poses a serious health risk for humans and animals.

Key words: deoxynivalenol, Fusarium spp., linseed, rapeseed, T-2 toxin, zearalenone,

\section{INTRODUCTION}

Fusarium spp. fungi control and mycotoxin content analyses are mostly done on various cereal samples, and there is little evidence on the occurrence of these fungi and their metabolites on oil crops' seed. It is known that linseed, winter and spring rape crops are badly damaged by Fusarium

Communicated by Edward Arseniuk 
wilt, whose causal agents $F$. oxysporum and $F$. avenaceum are also detected on the seed of these crops (Lange 2002, Ehrensing 2008). It was found that apart from $F$. oxysporum, $F$. avenaceum, in separate years linseed was infested with $F$. poae, $F$. heterosporum, $F$. proliferatum, $F$. graminearum (Gruzdevienè et al. 2006), while rapeseed was found to infested with F. culmorum, F. equiseti, F. moniliforme, F. poae (Lugauskas 2005), which are producers of deoxynivalenol (DON), zearalenone (ZEA), T-2 toxin (T2), HT-2 toxin (HT-2), fumonizin (FUM) and other mycotoxins (D'Mello et al. 1999, Bennett and Klich 2003). Some authors suggest that low DON levels are found in both rapeseed and linseed samples (Brazauskiene et al. 2006, Gruzdevienè et al. 2006), however ZEA and T-2 toxin incidence on the seed of these plants was not identified. Mycological analyses of rapeseed meal and cake revealed that $F$. graminearum, $F$. moniliforme, $F$. oxysporum fungi and DON and ZEA traces were present in practically each sample tested (Tabuc and Stefan 2005).

This paper assessed the frequency of Fusarium fungi observed in winter and spring oil seed rape and linseed analysed at the Institute of Agriculture, Lithuanian Research Centre for Agriculture and Forestry during 2007-2009 and identified and quantified the mycotoxins detected in the samples.

\section{MATERIALS AND METHODS}

\section{Sample handling}

$A$ total of 348 representative samples of oil crops' seeds produced during 2007-2009 were analyzed: 152 winter rapeseed, 120 spring rapeseed, 69 linseed and 7 rapeseed cake samples. They were collected in the central region of Lithuanian (Kèdainiai and Panevėžys distr.) immediately after seed harvesting. Oil crops were grown following the conventional technology.

\section{Fusarium spp. analysis}

The internal seed infestation with Fusarium fungi was tested on winter rape, spring rape and linseed samples (341 per crop) by an agar plate method (Mathur and Kongsdal 2003). The surface-sterilized seeds (400 per sample) were plated on a Potato Dextrose Agar (PDA) and incubated at 26 $\pm 2^{\circ} \mathrm{C}$ in the dark. The infection level of seed was evaluated in percent $(0-$ all seeds healthy, $100 \%$ - all seeds infected). Microscopic studies of Fusarium fungi were carried out after 7-8 days. The purified single spore cultures of Fusarium species were identified on the basis of their cultural and morphological characteristics according to Gerlach and Nirenberg (1982), Nelson et al. (1983) and Leslie et al. (2006). 


\section{Analysis of mycotoxins}

Oil crop seed samples (103 per crop) were collected at harvesting and analysed for deoxynivalenol (DON), zearalenone (ZEN), and T-2 toxin (T-2) contamination. The analysis was done by the CD-ELISA (competitive direct enzyme-linked immunosorbent assay) method (Wilkinson et al. 1992). The Veratox® quantitative test kits (Neogen corporation, Food Safety Diagnostics), approved by the AOAC Research Institute (Certificate N 950702) were used for the analysis. Mycotoxin extraction and tests were performed according to manufacturer's instructions. The optical densities of samples and controls from standard curve were estimated by a photometer Multiskan Ascent, using filter of $650 \mathrm{~nm}$. The data were computed using the Ascent Software. Measured absorbances were automatically converted to the mycotoxin concentration units $-\mu \mathrm{g} \times \mathrm{kg}^{-1}$. The results were estimated taking into account the lowest calibration curve's mycotoxin concentration value (LOD-limit of detection), which is for: DON $-100.0 \mu \mathrm{g} \times \mathrm{kg}^{-1}$ (ppb); ZEN $-10.0 \mu \mathrm{g} \times \mathrm{kg}^{-1}$ (ppb); T-2 - $7.5 \mu \mathrm{g} \times \mathrm{kg}^{-1}$ (ppb).

\section{Statistical analysis}

ANOVA was applied for the statistical processing of data. For data significance the Fisher test was used. Averages for the other data were calculated (Tarakanovas and Raudonius 2003).

\section{RESULTS AND DISCUSSION}

No Fusarium fungi were found in internal tissue of winter rapeseed in $2007-2008$ (Table 1), and in 2009, the contamination level amounted to $0.43 \%$. In 2007 - 2009, spring rapeseed internal infection with Fusarium fungi varied from $0.41 \%$ to $1.86 \%$. F. oxysporum and $F$. avenaceum species prevailed. In 2009, spring rape samples were found to contain $F$. dimerum which is a significant human pathogen (Marom et al. 2008). A higher Fusarium contamination level was identified on linseed $(3.5-14.5 \%)$. $F$. oxysporum, $F$. avenaceum, $F$. poae and other species prevailed in the samples. In 2007, contamination with the above-mentioned fungi was more than twice as high as that in 2008 or 2009. The higher Fusarium contamination of linseed might have been determined by the weather conditions, harvesting timing, or later maturity (Gruzdeviene et al. 2006).

Mycotoxin tests showed that irrespective of the fact that Fusarium spp. fungi were not found in internal tissue of winter and spring rapeseed, in 2007 DON was identified in $75-100 \%$, ZEA 92.3 - $100 \%$ samples tested, and traces of T-2 toxin were found in all winter and spring rapeseed samples tested (Table 2). The concentrations of T-2 identified were low (8.5-10.2 $\left.\mathrm{g} \mathrm{kg} \mathrm{k}^{-1}\right)$. Linseed samples were $100 \%$ contaminated with DON, ZEA, and T-2 toxin. Although the levels detected are not high, the risk lies in the fact that co-occurrence of all the three toxins was determined in each 
sample tested and the effects of their interaction on human and animal health have not been studied, since all of them affect different body systems (Bennett and Klich 2003, Tabuc and Stefan 2005).

Fusarium contamination in oil crops' seed in 2007-2009

Table 1.

\begin{tabular}{|c|c|c|c|}
\hline \multirow{2}{*}{ Oil crops } & \multicolumn{3}{|c|}{ Internal infection of oilseeds } \\
\hline & 2007 & 2008 & 2009 \\
\hline \multicolumn{4}{|c|}{ Winter oilseed rape } \\
\hline No. analyzed samples & 32 & 60 & 60 \\
\hline Mean of infection $\%$ & 0 & 0 & 0.43 \\
\hline Standard deviation & 0 & 0 & 0.22 \\
\hline Min values $\%$ & 0 & 0 & 0 \\
\hline Max values $\%$ & 0 & 0 & 3.0 \\
\hline Coefficient of variation $\%$ & 0 & 0 & 199.22 \\
\hline \multicolumn{4}{|c|}{ Spring oilseed rape } \\
\hline No. analyzed samples & 32 & 44 & 44 \\
\hline Mean of infection $\%$ & 1.11 & 0.41 & 1.86 \\
\hline Standard deviation & 0.77 & 0.11 & 0.94 \\
\hline Min values $\%$ & 0 & 0 & 0 \\
\hline Max values \% & 7.0 & 1.0 & 10.50 \\
\hline Coefficient of variation $\%$ & 208.37 & 91.76 & 167.16 \\
\hline \multicolumn{4}{|c|}{ Linseed } \\
\hline No. analyzed samples & 24 & 40 & 5 \\
\hline Mean of infection $\%$ & 14.5 & 3.5 & 5.2 \\
\hline Standard deviation & 1.65 & 0.42 & 2.65 \\
\hline Min values $\%$ & 8.0 & 2.0 & 0.5 \\
\hline Max values $\%$ & 19.0 & 5.5 & 15.5 \\
\hline Coefficient of variation $\%$ & 27.84 & 38.92 & 114.10 \\
\hline
\end{tabular}

In 2008, all winter and spring rapeseed samples tested (100\%) were contaminated with ZEA and T-2 toxin (Table 3), however a lower DON contamination (18.2\%) was identified in spring rapeseed samples. For winter rapeseed DON contamination was 4 times as high as that for spring rapeseed $(84 \%)$. Mycotoxin contamination on linseed differed from that on rapeseed. DON was identified in $100 \%$ of samples tested, ZEA in $47.4 \%$, 
T-2 in $30.4 \%$. Other researchers also identified low contents of DON and ZEA in all samples of rapeseeds and rapeseed meal tested using ELISA method (Tabuc and Stefan 2005).

Table 2.

Mycotoxin contamination in the seeds of various oil crops in 2007

\begin{tabular}{|c|c|c|c|}
\hline \multirow{2}{*}{ Level of contamination and concentration } & \multicolumn{3}{|c|}{ Mycotoxins $\left[\mu \mathrm{g} \times \mathrm{kg}^{-1}\right]$} \\
\hline & DON & ZEA & $\mathrm{T}-2$ \\
\hline \multicolumn{4}{|c|}{ Winter oilseed rape } \\
\hline No. of analyzed samples & 8 & 12 & 8 \\
\hline Sample contamination $\%$ & 100 & 100 & 100 \\
\hline Mean of contamination & 165.0 & 18.6 & 9.2 \\
\hline Min values & 153.5 & 10.6 & 8.5 \\
\hline Max values & 176.5 & 25.6 & 10.2 \\
\hline Standard deviation & 2.97 & 1.88 & 0.19 \\
\hline Coefficient of variation $\%$ & 5.10 & 34.92 & 5.96 \\
\hline \multicolumn{4}{|c|}{ Spring oilseed rape } \\
\hline No. of analyzed samples & 8 & 13 & 8 \\
\hline Sample contamination $\%$ & 75.0 & 92.3 & 100 \\
\hline Mean of contamination & 133.0 & 19.6 & 9.7 \\
\hline Min values & 0 & 0 & 8.2 \\
\hline Max values & 181.0 & 25.10 & 10.1 \\
\hline Standard deviation & 29.05 & 2.08 & 0.22 \\
\hline Coefficient of variation $\%$ & 61.76 & 38.34 & 6.43 \\
\hline \multicolumn{4}{|c|}{ Linseed } \\
\hline No. of analyzed samples & 6 & 6 & 6 \\
\hline Sample contamination $\%$ & 100 & 100 & 100 \\
\hline Mean of contamination & 155.3 & 19.4 & 15.9 \\
\hline Min values & 146.0 & 11.3 & 9.8 \\
\hline Max values & 163.5 & 24.1 & 22.1 \\
\hline Standard deviation & 2.78 & 2.40 & 2.60 \\
\hline Coefficient of variation $\%$ & 4.39 & 30.37 & 40.10 \\
\hline
\end{tabular}


Mycotoxin contamination in the seeds of various oil crops in 2008

\begin{tabular}{|c|c|c|c|}
\hline \multirow{2}{*}{ Level of contamination and concentration } & \multicolumn{3}{|c|}{ Mycotoxins $\left[\mu \mathrm{g} \times \mathrm{kg}^{-1}\right]$} \\
\hline & DON & ZEA & $\mathrm{T}-2$ \\
\hline \multicolumn{4}{|c|}{ Winter oilseed rape } \\
\hline No. of analyzed samples & 25 & 25 & 19 \\
\hline Sample contamination $\%$ & 84.0 & 100 & 100 \\
\hline Mean of contamination & 209.7 & 14.3 & $<\mathrm{LOD}^{*}$ \\
\hline Min values & 0 & $<\mathrm{LOD}$ & $<\mathrm{LOD}$ \\
\hline Max values & 278.3 & 32.3 & 11.6 \\
\hline Standard deviation & 18.85 & 1.45 & 0.72 \\
\hline Coefficient of variation $\%$ & 44.94 & 50.49 & 51.43 \\
\hline \multicolumn{4}{|c|}{ Spring oilseed rape } \\
\hline No. of analyzed samples & 11 & 11 & 9 \\
\hline Sample contamination $\%$ & 18.2 & 100 & 100 \\
\hline Mean of contamination & $<$ LOD & 14.3 & $<\mathrm{LOD}$ \\
\hline Min values & 0 & $<\mathrm{LOD}$ & $<\mathrm{LOD}$ \\
\hline Max values & 226.0 & 25.1 & 10.1 \\
\hline Standard deviation & 27.49 & 1.67 & 0.85 \\
\hline Coefficient of variation $\%$ & 222.49 & 38.74 & 43.26 \\
\hline \multicolumn{4}{|c|}{ Linseed } \\
\hline No. of analyzed samples & 19 & 19 & 23 \\
\hline Sample contamination $\%$ & 100 & 47.4 & 30.4 \\
\hline Mean of contamination & 209.7 & $<\mathrm{LOD}$ & $<\mathrm{LOD}$ \\
\hline Min values & 110.5 & 0 & 0 \\
\hline Max values & 271.7 & 22.5 & 8.6 \\
\hline Standard deviation & 13.21 & 1.69 & 0.56 \\
\hline Coefficient of variation $\%$ & 27.46 & 154.23 & 82.73 \\
\hline
\end{tabular}

*LOD - limit of detection

In 2009, mycotoxin tests were done in rapeseed and rapeseed cake samples (Table 4). DON and T-2 was found in $100 \%$ of linseed samples tested, ZEA in $40 \%$. It was noticed that in rapeseed cake DON concentrations were nearly twice as high as those in rapeseed samples (267.3-590.5 $\left.\mu \mathrm{g} \mathrm{kg}^{-1}\right)$. For rapeseed cake ZEA and T-2 contamination was present in $86 \%$ and $66.6 \%$ of samples 
tested. Using rapeseed cake with such a high contamination level as an additive in animal feed can be detrimental to animal health.

Mycotoxin contamination in linseed and rapeseed cake in 2009

\begin{tabular}{|c|c|c|c|}
\hline \multirow{2}{*}{ Level of contamination and concentration } & \multicolumn{3}{|c|}{ Mycotoxins $\mu \mathrm{g} \mathrm{kg}^{-1}$} \\
\hline & DON & ZEA & $\mathrm{T}-2$ \\
\hline \multicolumn{4}{|c|}{ Linseed } \\
\hline No. of analyzed samples & 10 & 10 & 10 \\
\hline Sample contamination $\%$ & 100 & 40 & 100 \\
\hline Mean of contamination & 115.5 & $<\mathrm{LOD}^{*}$ & 9.3 \\
\hline Min values & 109.8 & 0 & 8.7 \\
\hline Max values & 124.1 & 10.5 & 9.9 \\
\hline Standard deviation & 1.38 & 1.69 & 0.14 \\
\hline Coefficient of variation $\%$ & 3.79 & 129.11 & 4.70 \\
\hline \multicolumn{4}{|c|}{ Rapeseed cakes } \\
\hline No. of analyzed samples & 7 & 7 & 3 \\
\hline Sample contamination $\%$ & 100 & 86 & 66.6 \\
\hline Mean of contamination & 387.0 & 12.3 & 11.8 \\
\hline
\end{tabular}

*LOD - limit of detection

\section{CONCLUSIONS}

Monitoring of Fusarium fungi and DON, ZEA, T-2 mycotoxins in the seed and cake of Lithuania-grown oil crops showed that in separate experimental years (depending on the weather conditions, plant species and other factors) favourable conditions for their spread can occur, which, in terms of food safety, may result in a chain of risk factors. More attention should be paid to linseed contamination with Fusarium fungi and mycotoxins under field conditions, since our research found a higher contamination level in it. A higher Fusarium species diversity was established, which creates conditions for the spread of metabolites of more varied chemical composition.

Rapeseed cake used as an additional protein source intended to enrich feedstuffs can be a risk factor since research indicated practically every sample to be contaminated with DON, ZEA, and T-2 toxin. For mycotoxin risk assessment, the importance of Fusarium fungi and trichotecenes and zearalenone contamination of oil crop seeds warrants further study. 


\section{ACKNOWLEDGEMENTS}

Lithuanian Ministry of Agriculture's Programme "Mikotoksinų ir mikromicetų plitimas ir kontrolè aliejinių augalų sèklose" "Mycotoxin and fungi distribution and control in oil seeds" (Contract No. 8P-328).

\section{REFERENCES}

Bennett J.W., Klich M. 2003. Mycotoxins. Clin. Microbiol. Rev. 16(3), 497-516.

Brazauskienė I., Petraitienė E., Mankevičienė A. 2006. The effects of genotype and environmental factors on rapeseed contamination with mycotoxins and mycotoxin-producing fungi. Ekologija. 3,14-20.

D’Mello J.P.F., Placinta C.M., Macdonald A.M.C. 1999. Fusarium mycotoxins: a review of global implications for animal health, welfare and productivity. Anim. Feed Sci. Technol. 80, 183-205.

Gerlach W., Nirenberg H.I. 1982. The genus Fusarium - a pictorial atlas. Mitt Biol Bundesanst Land-u Forstwirsch Berlin-Dahlem, 406.

Gruzdevienė E., Mankevičienė A., Lugauskas A., Repečkienė J. 2006. The effect of environmental conditions on the variation of fungi and mycotoxin contents in oil flax seed. Ekologija. 3, 64-70.

Lange R. 2002. Fusarium wilt - a new disease of canola. http://www.umanitoba. ca/afs/ agronomists_conf/2002/pdf/lange.pdf

Leslie J.F., Summerell B.A., Bullock S. 2006. The Fusarium Laboratory Manual. Blackwell Publ. - Iowa, USA, 388 .

Lugauskas A. 2005. Potential toxin producing micromycetes on food raw material and products of plant origin. Botanica Lithuanica, Suppl. 7, 3-16.

Mathur, S.B., Kongsdal O. 2003. Common laboratory seed health testing methods for detecting fungi. ISTA. Denmark, Copenhagen, 425.

Marom E.M., Holmes A.M., Bruzzi J.F., Truong M.T., O’Sullivan P.J., Kontoyiannis D.P. 2008. Imaging of Pulmonary Fusariosis in Patients with Hematologic Malignancies. AJR 190, 1605-1609.

Nelson P.E., Tousson T.A., Marasas W.F.O. 1983. Fusarium species. An illustrated Manual for Identification. The Pennsylvania St. University Press. Pennsylvania, USA, 193.

Tabuc K., Stefan G. 2005. Assessment of mycologic and mycotoxicologic contamination of soybean. Sunflower and rape seeds and meals during 2002-2004. Archiva Zootechnika, 8, 51-56.

Tarakanovas P., Raudonius S. 2003. Agronominiu tyrimu duomenu statistinė analizè taikant kompiuterines programas ANOVA, STAT, SPLIT-PLOT iš paketo SELEKCIJA ir IRRISTAT. Akademija, 57.

Wilkinson A.P., Ward C.M., Morgan M.R.A. Eds. Lins-Kens, H.F., Jackson, J.F. 1992. Immunological analysis of mycotoxins. Plant toxin analysis. Springer-Verlag, Berlin 185-225. 